\title{
Vulnerability of the São Paulo Macro Metropolis to Droughts and Natural Disasters: Local to Regional Climate Risk Assessments and Policy Responses
}

\author{
Pedro Henrique Campello Torres ${ }^{1, * \mathbb{D}}$, Demerval Aparecido Gonçalves ${ }^{2}$, Flávia Mendes de Almeida Collaço ${ }^{3}(\mathbb{D}$, \\ Kauê Lopes dos Santos ${ }^{1}$, Katia Canil ${ }^{4}$, Wilson Cabral de Sousa Júnior ${ }^{5}$ and Pedro Roberto Jacobi ${ }^{1}$
}

1 Divisão Científica de Gestão, Ciência e Tecnologia Ambiental, Instituto de Energia e Ambiente (IEE), Universidade de São Paulo, Av. Prof. Luciano Gualberto, 1289—Butantã, São Paulo SP 05508-010, Brazil; kauegeo@gmail.com (K.L.d.S.); prjacobi@gmail.com (P.R.J.)

2 Engenharia de Infraestrutura Aeronáutica (PG-EIA), Instituto Tecnológico de Aeronáutica (ITA), Praça Marechal Eduardo Gomes, 50—Vila das Acacias, São José dos Campos SP 12228-900, Brazil; demervas@gmail.com

3 Escola de Artes, Ciências e Humanidades (EACH), Universidade de São Paulo, Rua Arlindo Béttio, 1000_Ermelino Matarazzo, São Paulo SP 03828-000, Brazil; flavia.collaco@usp.br

4 Centro de Engenharia, Modelagem e Ciências Sociais Aplicadas, Programa de Pós Graduação em Planejamento e Gestão do Território (PGT), Universidade Federal do ABC (UFABC), Av. dos Estados, 5001-Bangú, Santo André SP 09210-580, Brazil; katiaccanil@gmail.com

5 Núcleo de Estudos em Infraestrutura, Ambiente e Sustentabilidade-NINFA, Divisão de Engenharia Civil, Instituto Tecnológico de Aeronáutica, Praça Marechal Eduardo Gomes, 50-Vila das Acacias, São José dos Campos SP 12228-900, Brazil; wilson.cabral.ita@gmail.com

check for updates

Citation: Campello Torres, P.H.; Gonçalves, D.A.; Mendes de Almeida Collaço, F.; Lopes dos Santos, K.; Canil, K.; Cabral de Sousa Júnior, W.; Jacobi, P.R. Vulnerability of the São Paulo Macro Metropolis to Droughts and Natural Disasters: Local to Regional Climate Risk Assessments and Policy Responses. Sustainability 2021, 13, 114. https://dx.doi.org/ $10.3390 /$ su13010114

Received: 16 November 2020 Accepted: 21 December 2020 Published: 24 December 2020

Publisher's Note: MDPI stays neutral with regard to jurisdictional claims in published maps and institutional affiliations.

Copyright: $\odot 2020$ by the authors. Licensee MDPI, Basel, Switzerland. This article is an open access article distributed under the terms and conditions of the Creative Commons Attribution (CC BY) license (https:/ / creativecommons.org/ licenses/by/4.0/).
* Correspondence: pedrotorres@usp.br

\begin{abstract}
The São Paulo Macro Metropolis (SPMM) is one of the richest and most inequitable regions of the Global South and is already experiencing the impacts of severe climate events. This study analyzes climate risk assessments and policy responses for this territory as well as its vulnerabilities. The Index of Vulnerability to Natural Disasters related to Droughts in the Context of Climate Change (IVDNS-acronym in Portuguese) was used to identify and select the most vulnerable municipalities in the SPMM. Following vulnerability analysis, the municipalities were subjected to risk analysis in the context of existing Brazilian legislation. The results indicate that, despite having positive capacities to respond to climate change, the analyzed municipalities are far from advancing from the status quo or taking the actions that are necessary to face future challenges in a climate emergency scenario. The results indicate that, despite being the most vulnerable to droughts and natural disasters, the cities analyzed are not the most vulnerable in the São Paulo Macro Metropolis from a socio-economic point of view. On the contrary, these are regions that could have a strong institutional capacity to respond to present and future challenges.
\end{abstract}

Keywords: climate risk assessment; climate change policy; climate emergency; subnational approach; São Paulo Macro Metropolis

\section{Introduction}

Analysis of the climatic risk assessments and policy responses for the São Paulo Macro Metropolis (SPMM) is necessary and urgent. Lessons from the last severe drought (20132015) indicate the need for a regional policy response to climate issues, their interdependencies, and vulnerabilities [1]. This regional approach complements current perspectives that are focused on either the national or city level. One apparent reason for this lack of regional focus is the non-availability of regional or local climate change scenarios. There is also an absence of scenarios and technological innovations on the SPMM scale. However, there is an urgent need to conduct climate change risk and a policy response assessment for the region. The SPMM is the richest region in Brazil and one of the richest in the Global South. This 
assessment is important in order to prevent failure in planning for climate change impacts within the territory.

Extreme climate events already strongly affect the SPMM territory. Severe droughts, extreme rainfall, and floods have been occurring more severely in various cities in the region during different times of the year. The absence of anticipatory planning adds to barriers for implementing adaptation policies [2], which can lead to loss of life [3], and an increase in the pattern of vulnerabilities [4] and environmental inequalities in cities.

This study seeks to contribute to the climate debate on the SPMM [5] by addressing climate change from an original and interdisciplinary perspective. The SPMM region is composed of 174 municipalities, with more than 30 million inhabitants and covers an area of approximately $53,000 \mathrm{~km}^{2}$. It is located in the southeastern part of São Paulo State (Figure 1) and is comprised of five metropolitan regions (São Paulo, Campinas, Baixada Santista, Vale do Paraíba and Litoral Norte, and Sorocaba), two urban agglomerations (Jundiaí and Piracicaba), and a micro-region (Bragantina) [6]. Many aspects of this region have been analyzed by geographers, sociologists, economists, and urban planners, among others [7-11], due to its contemporary significance nationally and relevance for Latin America.

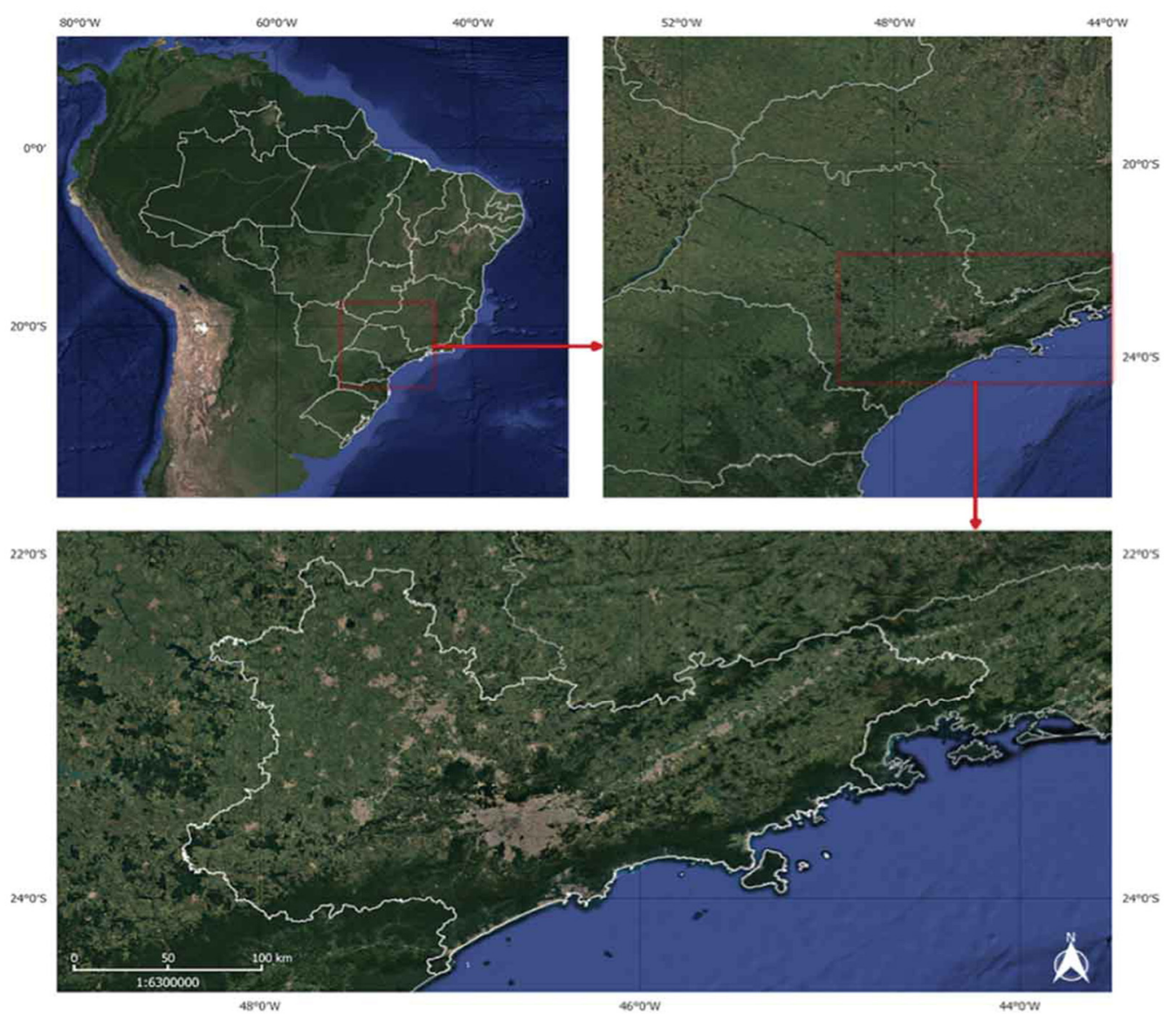

Figure 1. São Paulo Macro Metropolis. Source: Author's elaboration, 2020.

This analysis focuses on vulnerabilities related to drought and natural disasters. The choice of climate risk assessment related to drought does not eliminate or diminish the importance of other drivers of climate risk, including the tendency toward increased precipitation, sea-level rise, and other harmful effects brought about by extreme climate variability. On the contrary, this study seeks to provide an arsenal of tools, analyses, and insights to be used in the face of foreseen challenges [12]. 
In order to better understand the chosen territorial object, the SPMM municipalities with the highest vulnerability to droughts and natural disasters related to climate change were selected. The objective was to identify the most vulnerable location, analyze primary socio-economic data at the local level, and verify the municipalities' institutional capacities in light of their policy responses to address climate change risks and natural disasters.

Climate change-related drought risks are not a new research agenda. The concept has been discussed at the Intergovernmental Panel on Climate Change (IPCC) $[13,14]$ in the Managing the Risks of Extreme Events and Disasters to Advance Climate Change Adaptation Report (IPCC SREX) [15] and the Fifth Assessment Report [16]. However, based on recent extensive bibliometric analysis, Hagenlocher et al. [17] reported that there is still a gap between the conceptualization of drought vulnerability and risk assessment, and policy formulation to advance pathways toward a more drought-resilient society. This is especially the case in the context of the Global South.

Therefore, this research seeks to contribute to studies on climate risk assessments and policy responses under the Paris Agreement [18] with a focus on the regional and local levels, and emphasizes the need to produce, crosscheck, and analyze more data to provide more extensive support to decision-makers [19]. Science already provides accurate data for policies to adapt to climate change impacts. However, decision-making remains a challenge, especially on a subnational scale, in terms of a lack of technical capacity, the scale of prioritization required, or even conviction is unknown [20]. This article aims to fill this knowledge gap by providing insights into the impact of subnational policies related to climate change risks and does so from a perspective that incorporates both science and policy [12,21]. In this sense, the present work contributes to addressing this issue by providing data and examples of areas that should be priorities for decision-makers. This work is especially pertinent given the existing financial crisis, lack of investments for all areas, and insufficient institutional capacities to react to the effects of climate change.

The first part of this article seeks to contextualize the moment of climate emergency in which we live, from the perspective of the Paris Agreement. Understanding the context is fundamental for establishing a dialogue at the science-policy interface, which is what we propose to do in this work by observing the specificities of national and local scales. In the second section, we describe the materials and methods of our analysis. We present a stepwise methodological framework that includes the application of vulnerability indices and the verification of policy responses. In the final part of this article, we present the results and discuss the importance of these findings in view of the applied policy dialogue perspective.

\section{Climate Emergency and the Paris Agreement}

The Paris agreement is the most recent attempt to establish international cooperation regarding climate change [22]. This agreement was ratified during the 2015 United Nations Climate Change Conference (COP21) that was held in Paris. It was signed by 185 countries and is aimed at "holding the increase in the global average temperature to well below $2.0^{\circ} \mathrm{C}$ above pre-industrial levels and pursuing efforts to limit the temperature increase to $1.5^{\circ} \mathrm{C}$ above pre-industrial levels, recognizing that this would significantly reduce the risks and impacts of climate change." The agreement identifies adaptation to climate change as a "global challenge faced by all, with local, subnational, national, regional, and international dimensions" [23]. In a country like Brazil and a region like the SPMM, climate risk assessment is key to building effective adaptation plans and implementing adaptation projects.

Analysis of the global investment flux for mitigation and adaptation projects reveals a disparity in funding between the two [24]. In 2018, from a total of 579 billion dollars invested, $92 \%$ was used for mitigation projects and only $5 \%$ was used for adaptation projects. This is highly relevant since the Paris agreement recognized adaptation as a critical component of the global response to climate change. In the Katowice climate package rulebook, the Paris agreement explicitly articulated the mandate for nations to undertake and document adaptation progress, which may include the following: 
“(a) The implementation of actions, commitments, and/or adaptation efforts, (b) the process of formulating and implementing national adaptation plans, (c) assessing impacts and vulnerability concerning climate change, to formulate nationally determined prioritized actions, taking into account vulnerable people, places, and ecosystems, (d) monitoring and evaluation, and learning from adaptation plans, policies, programs, and actions, and (e) building the resilience of socio-economic and ecological systems, including through economic diversification and sustainable management of natural resources."

In response, 150 countries have included adaptation provisions in their pledges or nationally determined contributions (NDCs). As Berrang-Ford et al. (2019) point out, assessing governments' progress toward meeting adaptation commitments is a critical step in reducing vulnerability to climate change.

However, even if all nations comply with and meet their NDCs, a gap will remain that needs to be resolved to prevent the increase of $1.5^{\circ} \mathrm{C}$ to $2{ }^{\circ} \mathrm{C}$ in temperature [25]. According to Roelfsema et al. [25], Brazil is relatively close to the scenario of a $2^{\circ} \mathrm{C}$ increase, which suggests that these regions

"would mostly need to ensure that their national policies more closely lead to the NDC target (which may already be achieved through very recent policy updates). It should, however, be noted that cost-optimal implementation (equal marginal costs in all regions) leads to higher costs, as a percentage of GDP, in low-income regions and, therefore, is a fair way to implement the Paris agreement only if complemented by financial transfers" [25].

Until recently, Brazil has been an essential player in articulating the worldwide policy on climate change. Most of the country's emissions come from land-use changes and deforestation (44\%), followed by agriculture (25\%) and energy use, which includes fossil fuel use (28\%) [26]. This explains why Brazil is the only country in the G20 in which the main vector of $\mathrm{CO}_{2}$ reduction is in the AFOLU-agriculture, forests, and other land-use sectors, while, in all other G20 countries, emission reductions under the national policy scenario occur in the energy supply and transport sector.

Beginning with COP15 in 2009 in Copenhagen, Brazil assumed a pioneering position among developing countries $[27,28]$ when it announced voluntary goals to decrease its emissions by $36.1 \%$ to $38.9 \%$ by 2020 (against a reference scenario). These voluntary goals were translated into the National Policy on Climate Change (Law 12.187, December 2009). These targets were planned to be achieved through emission cuts from changes to land-use and deforestation ( $24.7 \%)$, agriculture ( $4.9 \%$ to $6.1 \%)$, energy use $(6.1 \%$ to $7.7 \%)$, and iron and steel production $(0.3 \%$ to $0.4 \%)$ [29].

In 2015, Brazil increased its commitments under the Paris Agreement by pledging emissions reduction of $37 \%$ by 2025 , and $43 \%$ by 2030 (relative to 2005 levels), in its Intended Nationally Determined Contributions (iNDC) [30]. To achieve these targets, the Brazilian iNDC highlighted its intentions to decrease deforestation, reforest degraded areas, expand the use of renewable energy sources, increase energy efficiency, and intensify agricultural and livestock production [31]. Nevertheless, both the National Policy on Climate Change and the iNDC pay less attention to the adaptation aspects of climate commitments.

The country's main framework for adaptation is the National Adaptation Plan (NAP) with a horizontal time extending to 2040. The NAP presents a general goal of climate change risk reduction for the country [32]. It seeks to ensure the satisfactory and coordinated implementation of sectoral and thematic risk management strategies by understanding agriculture, water resources, food and nutrition security, biodiversity, cities, disaster risk management, industry and mining, infrastructure, coastal areas, vulnerable peoples and populations, and health.

To reduce climate change risk, vulnerability, and the impacts thereof, the plan intends to initiate and support the development of research in adaptation technologies. In addition, it envisions the following programmatic outcomes: development of an agricultural risk and 
vulnerability monitoring and simulation system, development of indices based on a regional vulnerability analysis, developing medium and long-term vulnerability indicators, production of climate risk maps (local, regional, and national), classification of the country's regions based on climate risk for the main agricultural activities, creation of a vulnerability scale to identify areas for priority action, and the identification of Climate Change Vulnerability Populations for Territorial Management and Indigenous Land Environmental Policy.

At the state level, the São Paulo State Climate Change Policy [33] established the state's commitment to provide adaptations to combat the impacts of climate change and to contribute to the reduction of greenhouse gas emissions statewide. To that end, the policy states a dual need to provide adaptation measures capable of reducing emissions from natural systems as well as reducing society's vulnerability to the expected climate change effects. However, the policy has no clear statements of goals. The policy suggests the promotion of environmental education and social awareness about global climate change and calls for the need for the territory to identify vulnerabilities, which is followed by adaptation measures and preventive actions. Finally, the State Climate Change Policy seeks to promote a sustainable urban planning system with low environmental and energy impacts, including the identification of susceptible and vulnerable areas resulting from the disorderly occupation of the territory. Nevertheless, none of the municipalities analyzed in this study had developed a complete adaptation plan that includes a diagnosis of the current situation and climate risk assessment, nor had municipalities developed adaptation policies and propositions based on such assessments.

\subsection{Climate Risk Assessments and Policy Responses in the SPMM}

Cities at the forefront of activities to combat climate change are bastions of hope by many, in the event of nations failing with respect to climate change actions under the Paris Agreement [25]. However, the distribution of this burden, especially in the Global South, is complex because of the historical inequalities that exist in this region, which are far from being resolved. Illuminating this issue is crucial for more effective public policymaking to occur and necessitates the need to reduce inequalities and develop adaptation measures simultaneously [34].

Climate change increases the urgency of disaster risk management and prevention in the face of the increased frequency and intensity of extreme climate events. Floods and droughts will dramatically affect not only Brazil, but all countries in Latin America and the Caribbean, according to the recently published report from the United Nations Office for the Coordination of Humanitarian Affairs (OCHA), 2020. The OCHA report that documents the natural disasters of the past two decades in Latin America and the Caribbean shows that the region has suffered losses of $\$ 1$ billion caused by damages from 12 floods between 2000 and 2019 [35].

Disaster risk management scenarios reveal a mismatch between the preventive management measures required by the recent legislation and the techno-centric structure of civil defense mechanisms, the vulnerability of populations in high-risk areas, and limited social participation in taking ownership of the techno-scientific temperament and behavioral adaptation needed for living alongside climate change risks.

Thus, while the SPMM is a region of economic dynamism, it is essential to understand that, in its spatial totality, socio-economic inequalities are prevalent that were historically produced by economic development and urbanization.

The state of São Paulo is a pioneer in formulating policies and actions related to climate change in Brazil, approving, at the initiative of the executive, the State Policy on Climate Change (PEMC-acronym in Portuguese), State Law No. 13,798, of November 2009. After just over 10 years, there are few states and cities that have plans, laws, and policies for climate change adaptation in the country [36]. The governance plan of the SPMM region is the Action Plan (SPMM-AP), which serves as an instrument to guide the development and implementation of public policies and creates a new institutional arrangement for the governance of the macro-metropolitan territory. A detailed reading of the four volumes 
of the SPMM-AP reveals a strong orientation toward development, even though a verbal discourse on sustainability is present throughout.

The predominant vision is of integration in favor of development and economic growth. The importance of ecosystem services is recognized, as well as their relevance to well-being and quality of life. There is a recognition of the need to integrate the territory and traditional sectoral policies and establish multilevel dialogues and polycentricity. This is demonstrated in the SPMM-AP Strategic Vision, which aims to "formulate integrated public policies for the territory of SPMM and involve the other levels of government, the private sector, and society in proposal and implementation of actions and in metropolitan projects," especially regarding climate change and water security.

However, climate variability is not a priority for the SPMM-AP, though plans for new infrastructure projects do take into account such scenarios, with greater emphasis on adaptive capacity and resilience. The SPMM-AP presents, in its four volumes, a few features that link development with climate change and the PEMC. However, the first volume of the SPMM-AP states that PEMC is a reference for its development. One of its guidelines states that it, "encourage[s] the adoption of environmental sustainability requirements and implement[s] the goals of PEMC, [by] defining strategies to mitigate and adapt to these changes" [37]. The goals mentioned earlier appear in Volumes 2, 3, and 4. They are aligned to the energy and transport sector (Vol. 3), urbanization (Vol. 1), and environmental development (Vol. 1).

\subsection{Addressing Climate Change Risks at the Local Level}

In Brazil, risk and disaster prevention policies have increased in number in recent years, which is an important achievement from a legal framework perspective. The goal, for example, of Law 12.608/12 was to institute the National Policy for Civil Protection and Defense (PNPDEC - acronym in Portuguese), which was based on prevention, mitigation, preparation, response, and recovery actions aimed at civil protection and defense. The PNPDEC must be integrated with territorial planning, urban development, health, environment, climate change, water resources management, geology, infrastructure, education, science and technology policies, and other sectoral policies to promote sustainable development [38] that aligns with the National Climate Change Policy-PNMC [29] and State Climate Change Policy [33].

At the international level, the Hyogo Framework for Building the Resilience of Nations and Communities for Disasters (2005-2015) and the Sendai Framework for Disaster Risk Reduction (2015-2030) aim to develop and implement actions for disaster risk reduction to make communities more resilient. The PNPDEC contains objectives that include identification and assessment of hazards, susceptibilities, and vulnerabilities to disasters in order to prevent or reduce their occurrence, based on the actions proposed by the international frameworks for disaster risk reduction. The risk mapping, for example, is represented by geotechnical maps, which must be elaborated so that they can contribute to and integrate with the master plans of the municipalities.

The identification of hazards and risks related to landslides and floods can be represented by combining the mapping of risk management and territory planning into geotechnical maps, which must be elaborated and integrated into PNPDEC. Simões et al. [2], analyzing the context of some Brazilian municipalities on climate change, stated that differing perceptions on the issue, availability, and accessibility of information, existing management context, and leadership are emerging critical barriers for adaptation. Planning and governing in the face of climate change, therefore, needs to adjust its practice to fit local demands. A formal participatory planning process is not enough. It is necessary to ensure there is an arena for community actors to propose actions, thereby breaking the business-as-usual paradigm. It is not merely a question of including bottom-up discussion, even though it must start from there.

Authors like Schlosberg [39] suggest a new framework approach for the analysis of social vulnerabilities in the context of adaptation. The proposal is to use "capabilities" as a 
reference for the assessment of climate adaptation policies in order to prevent them from worsening existing social vulnerabilities. According to Schlosberg, the concept would also have the potential to integrate different dimensions of environmental justice: distributive, procedural (participatory), and recognition (related to cognitive justice) [40]. For cases in the Global South, even in its richest region, an imperative mediation to adapt the theme to the context rather than suggestions seems to be the only possibility.

From this perspective, the engagement of groups and communities is necessary for collaborative projects, given that exclusively regulatory, authoritarian, or technical approaches are inadequate in the face of challenges faced in a complex system. Operational processes, especially those of a collaborative nature (recognized as co-learning), have the potential to generate innovations, collective commitments, and citizenship practices guided by the experience of thinking and acting in a dialogical, supportive way for the construction of new governance and monitoring protocols to reduce the scope of climate change impacts. We start from this perspective and seek to understand the most vulnerable areas of the territory that should receive priority actions by the state in combating the effects of climate change.

\section{Materials and Methods}

This article is divided into five linked but interdependent methodological procedures (Figure 2). The first and second procedures seek to identify those municipalities of the SPMM that are considered most vulnerable, through the application of the Index of Vulnerability to Natural Disasters related to Droughts in the Context of Climate Change (IVDNS-acronym in Portuguese). The third step is a cartographic representation of the most vulnerable municipalities of the SPMM, and the fourth step is the selection of the most vulnerable municipalities (19 municipalities among all the 174 cities of the SPMM). The final step verifies the socio-economic patterns of the municipalities, thus identifying and analyzing the current performance of these municipalities by considering the legislation or initiatives for risk and disaster management. All steps are described below.

Municipalities most vulnerable to drought and natural disasters in SPMM

Extraction, from the national base of the IVDNS $(5,070$ municipalities), of the Municipalities of São Paulo Macrometropolis (174 municipalities) present in the IVDNS.

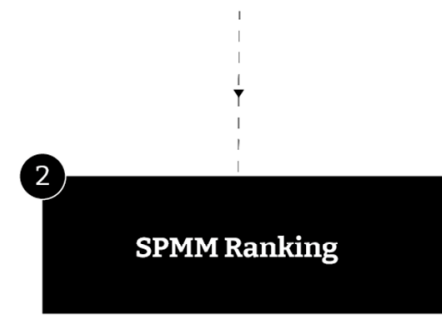

After extracting the 174 municipalities from SPMM, data organization and ranking in order of the places most vulnerable to droughts and natural disasters according to the IVDNS.

\section{4}

Most vulnerable to droughts and natural disasters according to the IVDNS

Among the 174 municipalities ranked by order of the most vulnerable, selection of 19 municipalities considered the most mulnerable among the 174. All have, according to the IVDNS, an index greater than 4 , in the representation up to 5 , in the IVDNS.

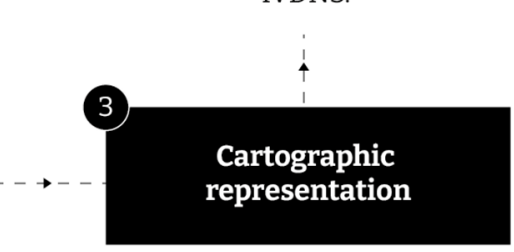

Elaboration of a map with the 174 municipalities of SPMM, indicating the places most vulnerable to droughts and natural disasters according to the IVDNS.

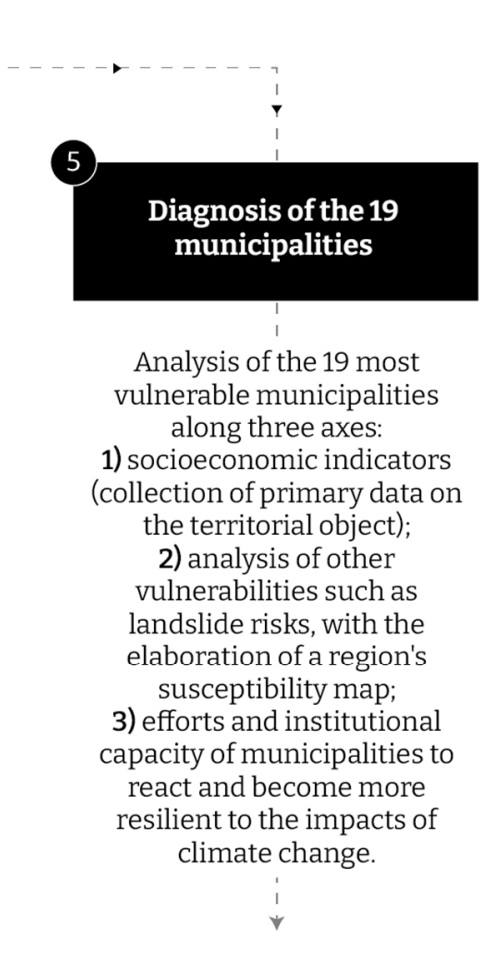

Figure 2. Methodology steps. Source: Author's elaboration, 2020. 
The IVDNS is a national index of climate change, drought, and natural disaster vulnerability among all Brazilian municipalities (5070 in total). Drought represents the category of natural disasters with the highest record of occurrences in Brazil. Approximately $70 \%$ of the municipalities affected by some climatic disaster were affected by drought, which equates to at least 12 million people affected annually. The IVDNS was developed in response to the lack of studies on these topics in Brazil and to contribute to the National Plan for Adaptation to Climate Change, launched in 2016-IVDNS is an initiative of the Ministry of Environment, the Ministry of Integration, Brazil, and World Wide Fund for Nature (WWF-Brazil). It is an index composed of variables and sub-indices that is represented in three dimensions: (i) climatic, (ii) socio-economic, and (iii) physical-environmental. All of the climatic variables that were incorporated into the index are derived from the raw data of two different climate models-ETA-HadGEM-ES and ETA-MIROC-5. These models represent the nesting of the Eta regional model with the respective global models. The version of Eta used in this study is characterized by downscaling (climate regionalization of $20 \mathrm{~km}$ spatial resolution for Brazil) and has been adopted in previous studies of climate change scenarios.

In order to identify the relative aspects of vulnerability to droughts in the context of climate change, we built a sub-index of climatic exposure to meteorological drought based on anomalies/increments of three climatic variables.

1. $f$ Average accumulated rainfall (MPPT) in 12 months: extracted directly from the Eta-20 km model rounds.

2. $f$ Standard deviation of the average accumulated precipitation over 12 months: variable that represents how strong the variability of the precipitation regime is over a 12-month period.

3. $f$ Drought power: created and adapted from the standardized data of the precipitation evapotranspiration index (SPEI), which consider the magnitude, frequency, and duration of severe droughts (SPEI < -1.50) during the period analyzed.

Five variables are also taken into consideration for the construction of the IVDNS based on socio-economic, demographic, land-use, and water management data: (1) infant mortality rate, (2) percentage of the population below the poverty line, (3) demographic density of municipalities, (4) water supply and demand, and the type of main sources for public supply, and (5) land-use. Regarding adaptive capacity, indices such as the illiteracy rate, Gini index, and Human Development Index (HDI) were taken into account.

The IVDNS identifies those municipalities that are most vulnerable to the climate change-related effects of meteorological drought. The index is classified into the periods 2011-2040, 2041-2070, and 2071-2099. It considers the sub-indices of exposure and sensitivity as potential impacts, as well as adaptive capacity. For the Exposition sub-index, the ETA-HadGEM-ES and ETA-MIROC-5models [22] were considered due to their assertions for temperature and precipitation projections on the Brazilian territory. Furthermore, data from these GCM with regionalization for the studied site was sourced from an open platform.

For this research, IVDNS data for the 2011-2040 from the ETA-HadGEM2-ES Model of the RCP 4.5 (Representative Concentration Pathways 4.5) scenario were used, 2011-2040 being the current period. This scenario is considered the most likely one if global climate goals are reached. The data were defined by the ETA-HadGEM2-ES model because the correlation of its results with the observed data is slightly higher than that of Eta-MIROC5 for the data on precipitation and maximum summer and winter temperatures in the southcentral region of Brazil [41]. The RCP 4.5 scenario was selected because it is an intermediate scenario, which is neither most nor least optimistic, which considers the mitigation of greenhouse gas emissions in which the stabilization of the radiative forcing occurs until the year 2100 [42].

The following is the equation that represents the IVDNS and the interaction between the sub-indices.

$$
\mathrm{IVNDS}=\frac{(\mathrm{EXP}+\mathrm{SENS})}{2} \times\left[0.5+\left(\frac{1-\mathrm{CA}}{2}\right)\right]
$$


Equation (1) - Formula used in calculating the Index of Vulnerability to Natural Disasters related to Droughts in the Context of Climate Change (IVDNS) composed of climate exposure (EXP), sensitivity/susceptibility (SENS), and adaptive capacity (CA).

For the IVDNS, Equation (1) was structured with the premise of identifying the existing vulnerability contrasts in Brazil and representing how the sub-indices of exposure (EXP), sensitivity (SENS), and adaptive capacity (CA) are related. Thus, the vulnerability index addressed in this study has the main objective of identifying the locations that are critically impacted by drought disasters, considering all aspects previously mentioned.

From the 5070 Brazilian cities present in the database, the 174 that lie within the SPMM region were extracted. From the ranking of the 174 municipalities in the SPMM, it was possible to identify those with the highest rates of disasters in the form of natural drought in the context of climate change. Of the 174 municipalities, 19 were selected as the most vulnerable to drought and natural disaster related events. They were analyzed individually, from both a socio-economic perspective, and a risk and disaster management policy response perspective.

The social and economic aspects that were analyzed included population density, gross domestic product (GDP), monthly income, and the HDI-a statistic composite index of life expectancy, education, and per capita income indicators, which are used to rank countries into four tiers based on human development. The primary data were collected from federal government public platforms and the state of São Paulo. Next, a procedure was adopted to verify the pattern of social vulnerability in the municipalities. It is vital to understand whether the municipalities affected most by drought are also home to the most vulnerable populations in the region and to identify the institutional capacity for reaction, in terms of climate policy.

With regard to risk and disaster management, three types of risk and disaster mapping were carried out on the 19 municipalities, considering the National Civil Protection and Defense Policy [38], namely, susceptibility mapping, urban aptitude geotechnical mapping, and risk mapping. We verified whether the cities signed the protocol of the Resilient Cities Campaign (HYOGO-2005-2015 and SENDAI-2015-2030 frameworks) and are included in the Civil Defense Prevention Plan (São Paulo State Decree N ${ }^{\circ} 42565 / 97$ ). The objective of these procedures was to understand the current performance of these municipalities both from a climate assessment and a policy response perspective.

The methodology that we describe connects to the dialogue on the uncertainties associated with the current climate change scenario and doubts about the success of the Paris Agreement. In this sense, the article seeks to situate the role of the state of São Paulo in this debate, wherein, given the disbelief in multilateralism, subnational contribution is imperative.

\section{Results}

4.1. Municipalities Most Vulnerable to Climate Change-Related Drought and Natural Disasters in the SPMM

From the indicators extracted from IVDNS, 19 of the most vulnerable municipalities within the SPMM were selected for analysis (Figure 3). Of the 19 municipalities, 18 are located in the Metropolitan Region of São Paulo (SPMR), while one is located in the Vale do Paraíba e North Coast Metropolitan Region (VPNL). The heterogeneity is evident in the demographic scope with respect to both total population and population density. Figure 4 reflects the cartographic representation of the IVDNS from ETA-HadGEM2-ES RCP 4.5 for Brazil, and then for the SPMM territory. 


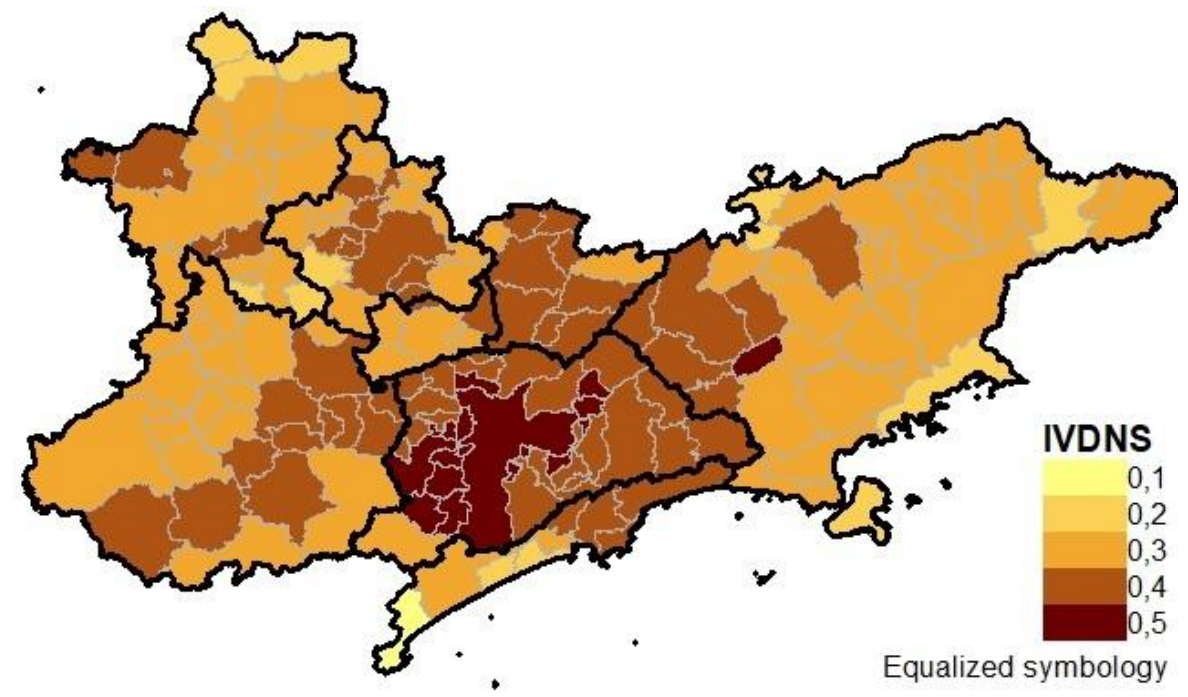

Figure 3. Cartographic representation of the São Paulo Macro Metropolis (SPMM) according to the Index of Vulnerability to Natural Disasters related to Droughts in the Context of Climate Change (IVDNS). Source: Author's elaboration, 2020. Data from: MMA/WWF, 2017.

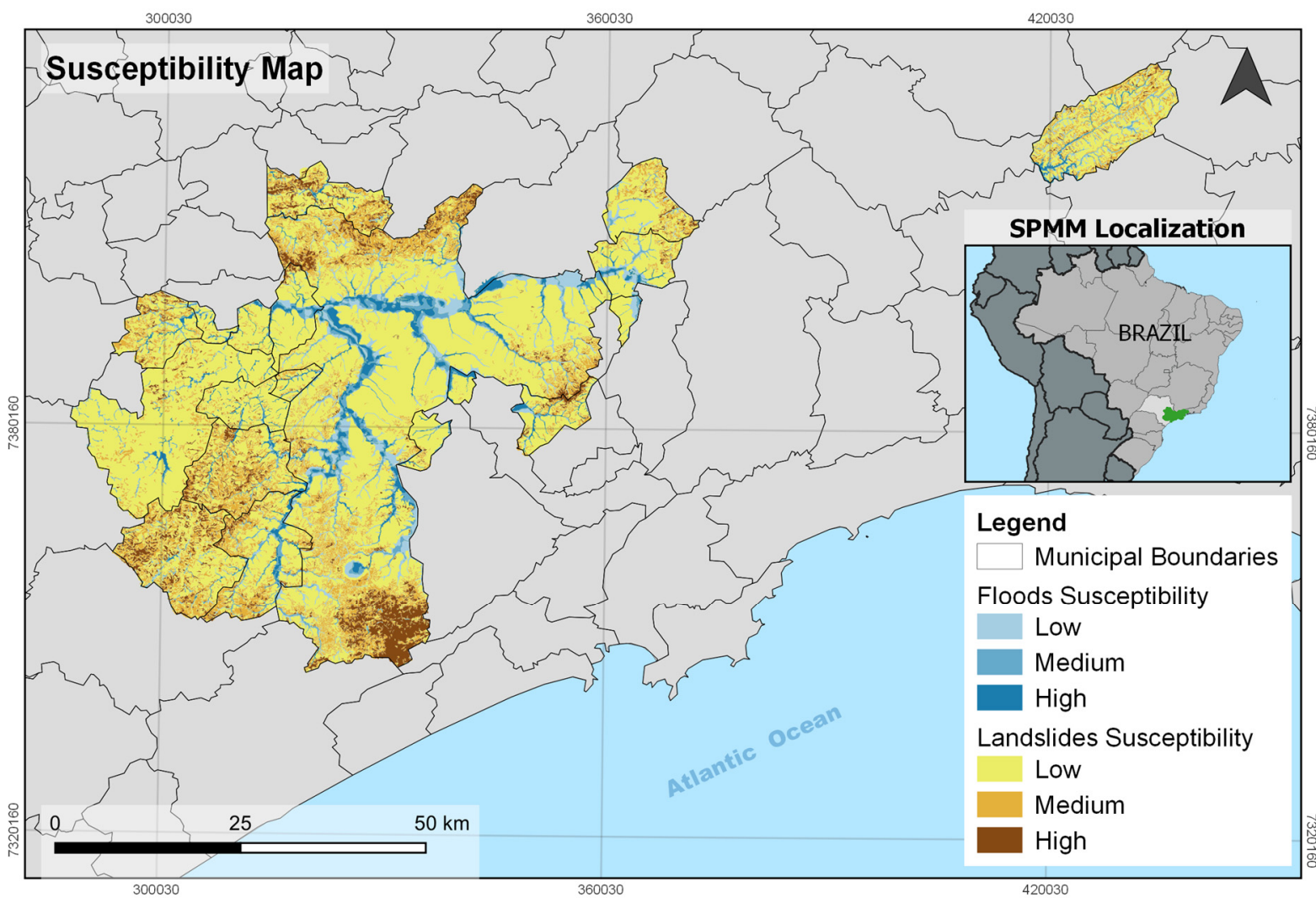

Figure 4. Susceptibility map. Author's elaboration, 2020.

The vulnerability scale ranges from 0.1 to 0.5 , with higher values representing greater vulnerability. Figure 4 shows that the greatest concentration of vulnerability lies in the central nuclear fraction where the metropolitan region of São Paulo is located. Table 1 presents the social and economic characteristics of the 19 municipalities considered in this study. All record a vulnerability index of more than 0.4. 
Table 1. Social and economic characteristics of 19 selected municipalities in the São Paulo Macro Metropolis (SPMM). Author's elaboration. Source: IBGE, 2020.

\begin{tabular}{|c|c|c|c|c|c|c|}
\hline Municipality & $\begin{array}{c}\text { Total } \\
\text { Population }\end{array}$ & Density & $\begin{array}{c}\text { Monthly } \\
\text { Income (USD) }\end{array}$ & HDI & $\begin{array}{l}\text { Metropolitan } \\
\text { Region or Urban } \\
\text { Agglomeration }\end{array}$ & $\begin{array}{l}\text { IVDNS ETA- } \\
\text { HadGEM2-ES } \\
\text { RCP } 4.5\end{array}$ \\
\hline Arujá & 74,905 & 779.33 & 441.06 & 0.784 & SPMR & 0.464 \\
\hline Caieiras & 86,529 & 900.37 & 404.23 & 0.781 & SPMR & 0.428 \\
\hline Carapicuíba & 369,584 & $10,698.32$ & 341.75 & 0.749 & SPMR & 0.443 \\
\hline Cotia & 201,150 & 620.81 & 522.27 & 0.78 & SPMR & 0.419 \\
\hline Diadema & 386,089 & $12,1536.99$ & 334.31 & 0.757 & SPMR & 0.494 \\
\hline Embu & 240,230 & $3,412.89$ & 280.57 & 0.735 & SPMR & 0.492 \\
\hline Embu-Guaçu & 62,769 & 403.32 & 305.41 & 0.749 & SPMR & 0.443 \\
\hline Itapecerica da Serra & 152,614 & $1,011.57$ & 288.26 & 0.742 & SPMR & 0.474 \\
\hline Itapevi & 200,769 & $2,428.88$ & 281.00 & 0.735 & SPMR & 0.400 \\
\hline Itaquaquecetuba & 321,770 & $3,895.24$ & 244.58 & 0.714 & SPMR & 0.496 \\
\hline Jambeiro & 5,349 & 29.01 & 399.42 & 0.756 & VPLN & 0.411 \\
\hline Jandira & 108,344 & $6,207.76$ & 404.59 & 0.76 & SPMR & 0.443 \\
\hline Mauá & 417,064 & $6,741.41$ & 345.33 & 0.766 & SPMR & 0.407 \\
\hline Osasco & 666,740 & $10,264.80$ & 448.25 & 0.776 & SPMR & 0.474 \\
\hline Poá & 106,013 & $6,141.05$ & 336.82 & 0.771 & SPMR & 0.437 \\
\hline São Caetano & 149,263 & $9,736.03$ & 934.13 & 0.862 & SPMR & 0.443 \\
\hline São Lourenço da Serra & 13,973 & 74.99 & 300.57 & 0.728 & SPMR & 0.429 \\
\hline São Paulo & $11,253,503$ & $7,398.26$ & 666.84 & 0.805 & SPMR & 0.430 \\
\hline Taboão da Serra & 244,528 & $11,994.31$ & 393.17 & 0.769 & SPMR & 0.504 \\
\hline
\end{tabular}

\subsection{Socio-Economic Indicators}

The SPMM is the most economically dynamic macro-region in Brazil. It contains hightech industries, multiple and diversified commercial services, high-productivity agribusinesses, and the most extensive and efficient transport and distribution systems as well as some of the leading scientific and innovation centers in Latin America. Measuring this dynamism in terms of wealth generation, the SPMM's GDP was 0.47 trillion USD in 2016, which is equivalent to $25 \%$ of the GDP of Brazil [6]. However, this region is also characterized by extreme socio-economic inequalities [43]. These are evident in the urban spaces where there is a scarcity of infrastructure and services in some areas, but abundant in others. This imbalance results from the spatial selectivity of public and private investments in different sectors of the economy over time, as different authors have already observed [44-47].

Table 1 represents the heterogeneity of the macro metropolitan territory. The city of Jambeiro, for example, located in the administrative region of São José dos Campos, has just over 5000 inhabitants, while the municipality of São Paulo has 11.2 million. Some of the lowest population densities are found in Jambeiro and the municipality of São Lourenço da Serra. The lower population densities may be related to the presence of areas intended for activities in the primary sector of the economy, especially agriculture and livestock farming, or areas designated as environmentally protected. In contrast, municipalities such as Osasco, Carapicuíba, Diadema, and Taboão da Serra have population densities between 10,000 and 12,100 inhabitants [48]. In municipalities characterized by high population density, densification in subnormal agglomerates (favelas) is very common, especially in the municipalities that form the SPMR, which creates a problem with access to scarce drinking water during severe drought, thus further increasing their vulnerability. 
The generation of wealth also varies significantly-almost 212.76 million USD in the state capital, 23.4 million in Osasco, and 62.61 thousand USD in São Lourenço da Serra in 2017 [48]. These variations are closely linked to the density of activities in the tertiary sector in the city of São Paulo, covering commercial enterprises and services that operate within a broad spectrum of capitalization, generating the most significant volume of jobs in the state and the country. In the SPMR, this increase in wealth generation from the tertiary sector is decreasing and, in many cities, industries are gaining prominence in the generation of wealth, as in Mauá, Osasco, and São Caetano.

The variations in the monthly income of residents of the region and the HDI (based on per capita income, literacy rate, and life expectancy) are highlighted in Table 1 . The last national census of 2010 indicates that the average monthly income of the residents of a city like Itaquaquecetuba was $\$ 243.14$ USD, which is three times lower than that of a municipality such as São Caetano, where the average monthly income was \$928.67 USD in the same year. In 2010, São Caetano recorded one of the best HDIs in Brazil (0.862), while Itaquaquecetuba recorded the worst (0.714) [48].

Among the 19 municipalities, São Paulo and São Caetano have HDIs $>0.8$, which is considered "very high". The two municipalities also have high GDPs, which indicates the availability of enough resources to plan for the future in the face of climate change. Even in the municipality with the lowest HDI value, Itaquaquecetuba, the index is still considered "high", which shows that the municipalities that are among the most vulnerable to droughts and natural disasters are not necessarily those facing the greatest disparities in the state of São Paulo.

\subsection{Analysis of Other Vulnerabilities Using a Region's Susceptibility Map}

Three types of maps are used to diagnose other vulnerabilities such as landslide risks. Each map has a specific function and scale. The three main maps applied to territorial planning are Susceptibility Maps (SM)—scale 1:25,000, which depicts land compartments along with the possibility of occurrence of landslides and flooding processes in the compartments, based on the degree of susceptibility (high, medium, and low). Urban Aptitude Geotechnical Maps (UAGM)—scale 1:10,000, which aims to provide guidelines for land-use, considering the limits and potential of the physical environment based on its characteristics, in order to avoid new risk situations, and Risk Maps (RM)-scale $\leq 1: 2000$, which present the sectors affected by landslides, riverbank erosion, and floods and the respective degrees of risk, indicating the interventions to reduce risk through infrastructure measures. The map also indicates those houses that should be removed to avoid risk (Table 2). The SPMM Susceptibility Map (SM) was used for this study (Figure 4). The SM shows the degrees of susceptibility for landslides and floods for the municipalities that also experience drought risks. This information is important because it is challenging to manage disasters under scenarios of both excess and lack of water.

\subsection{Efforts and Institutional Capacity of Municipalities to React and Become More Resilient to the} Impacts of Climate Change

Considering risk and disaster management for the 19 municipalities from the perspective of Law 12.608/12, we realize that the application of legal instruments in these municipalities is diverse.

In addition to these procedures, there are other important disaster risk reduction strategies, such as the "Making Cities Sustainable and Resilient Campaign", which aims to support local governments in strengthening resilience in the face of disasters, as part of implementing the Sendai Framework at the local level.

Brazil is the country with the largest number of municipalities that have signed the protocol of the Resilient Cities Campaign [49]. Municipalities that signed the campaign are committed to defining priorities and taking action on risk and disaster management. They are also committed to increasing the level of awareness and perception of local managers in order to make these cities resilient. Unfortunately, these plans have not been implemented and the participatory processes lack representation in the formulation of the agenda [50]. 
Of the 19 municipalities studied in the SPMM, only Arujá, Embu, Embu-Guaçu, and Itapevi have not joined the campaign.

In spite of all this planning, most action is still in response to emergencies. For instance, the 19 municipalities that were studied have preventive civil defense plans. This implies having an emergency preparedness and response plan, which can be well-executed by the institutions involved. In terms of preventive actions, mapping is essential to assist mitigation and plan for urban expansion. With the approval of Law 12.608/12 and financial support from the federal and state governments, almost all municipalities have undertaken one or more types of mapping. However, integration of the mapping results into master plans of municipalities is still in its infancy. Itapevi is a municipality that recently elaborated its master plan and used risk mapping to establish macro zoning and spatial planning.

There is a lack of dialogue between technical and political establishments. This prevents the integration of policies that can effectively address climate change issues. This limitation is not favorable for the proper management of climate change or its related risks and disasters that affect Brazil, such as droughts, floods, landslides, coastal erosion, and undertow. However, the results (Table 2) indicate that all 19 municipalities in this study have civil defense prevention plans. Only four municipalities did not adhere to the protocol of the Resilient Cities Campaign (HYOGO 2005-2015 and SENDAI 2015-2030 Frameworks).

Table 2. Policies and plans for territorial planning and resilience. Author's elaboration, 2020.

\begin{tabular}{|c|c|c|c|}
\hline Municipality & $\begin{array}{l}\text { Mapping Applied to Risk } \\
\text { Management and Territory } \\
\text { Planning (Law 12.608/12) }\end{array}$ & $\begin{array}{l}\text { Signatory of the Resilient } \\
\text { Cities Campaign (HYOGO } \\
\text { 2005-2015 and SENDAI } \\
\text { 2015-2030 Frameworks) }\end{array}$ & $\begin{array}{l}\text { Civil Defense Prevention } \\
\text { Plan (São Paulo State } \\
\text { Decree N } N^{\circ} 42.565 / 97 \text { ) }\end{array}$ \\
\hline Arujá & $\mathrm{SM} / \mathrm{RM}$ & $\mathrm{NO}$ & YES \\
\hline Caieiras & $\mathrm{SM} / \mathrm{UAGM} / \mathrm{RM}$ & YES & YES \\
\hline Carapicuiba & $\mathrm{SM} / \mathrm{RM}$ & YES & YES \\
\hline Cotia & $\mathrm{SM} / \mathrm{RM}$ & YES & YES \\
\hline Diadema & $\mathrm{SM} / \mathrm{UAGM} / \mathrm{RM}$ & YES & YES \\
\hline Embu & $\mathrm{SM} / \mathrm{RM}$ & $\mathrm{NO}$ & YES \\
\hline Embu-Guaçu & $\mathrm{SM} / \mathrm{RM}$ & $\mathrm{NO}$ & YES \\
\hline Itapecerica da Serra & $\mathrm{SM} / \mathrm{UAGM} / \mathrm{RM}$ & YES & YES \\
\hline Itapevi & $\mathrm{SM} / \mathrm{UAGM} / \mathrm{RM}$ & $\mathrm{NO}$ & YES \\
\hline Itaquaquecetuba & $\mathrm{SM} / \mathrm{RM}$ & YES & YES \\
\hline Jambeiro & - & YES & YES \\
\hline Jandira & $\mathrm{SM}$ & YES & YES \\
\hline Mauá & $\mathrm{SM} / \mathrm{UAGM} / \mathrm{RM}$ & YES & YES \\
\hline Mogi das Cruzes & $\mathrm{SM} / \mathrm{RM}$ & YES & YES \\
\hline Osasco & $\mathrm{SM} / \mathrm{RM}$ & YES & YES \\
\hline Poá & $\mathrm{SM} / \mathrm{RM}$ & YES & YES \\
\hline São Caetano do Sul & $\mathrm{SM} / \mathrm{RM}$ & YES & YES \\
\hline São Paulo & $\mathrm{SM} / \mathrm{RM}$ & YES & YES \\
\hline Taboão da Serra & $\mathrm{SM} / \mathrm{RM}$ & YES & YES \\
\hline São Lourenço da Serra & SM & YES & YES \\
\hline
\end{tabular}




\section{Conclusions}

The present work contributes to reducing the knowledge gap that exists between data, cartographic representation, and the identification of localities that should be prioritized by decision-makers for developing strategies aimed at alleviating climate change risks in the São Paulo Macro Metropolis. An important finding of the study is that climate change planning is ineffective at the regional level despite the existence of a formal planning instrument (the SPMM-AP). It also does not follow the state policy on climate change, or even policy at the local level.

The identification of priority areas where vulnerability is greatest should guide decisionmakers in developing climate change strategies. This is especially so in the context of the financial crisis in the Global South, where lack of investments across areas and limited institutional capacity to react to extreme climatic effects persist. The objective of this study was to assess the climate risk of municipalities in the SPMM that are most vulnerable to droughts and natural disasters related to climate change using the IVDNS. Knowledge about the territory and its physical and social vulnerabilities are prerequisites for assessment and serve as the basis for formulating public policies. Hence, we sought to highlight the policies that are presently in effect and the municipalities that currently adhere to these policies.

The results of this study reinforce the maxim that it is at the local level that the processes of concrete action on adaptation to climate change materialize. For example, the municipality of Itaquaquecetuba, recorded the lowest "high" HDI value, implying that, in the case of the SPMM, the municipalities that are among the most vulnerable to droughts and natural disasters are not necessarily the most unequal municipalities in the state of São Paulo.

Although the majority of the municipalities did not have climate change policies or plans, risk analyses and policies do exist for all 19 municipalities. The results indicate that, despite having positive capacities to respond to climate change, the municipalities studied still seem far from moving forward from the status quo planning approach. The findings indicate that cities in the SPMM, despite being the most vulnerable to droughts and natural disasters, are not the most vulnerable from a socio-economic point of view. On the contrary, there are regions that have better institutional capacity to respond to present and future challenges. Thus, it seems that there is a path forward. Action must be taken to advance from the established baseline and develop more robust strategies for adaptation and resilience in the SPMM. For this, the top-down approach will not suffice. Creating action plans at the local level, formulating policies for the region, and observing their interdependencies are necessary to develop robust plans of action and collaborative efforts.

The evidence presented, although corroborated by the results of the Brazilian iNDC, from the Paris Agreement, will not be enough. Brazil's climate voluntary goals do not address the issue of adaptation at the subnational scale. Therefore, even if the municipalities fulfill their responsibilities within their capabilities, it is still not enough considering the enormity of the present and future challenges predicted by the climatic scenarios. The results showed that most municipalities have already identified risks, disasters, and vulnerabilities. However, in order to prevent tragedies, there is a need to go beyond risk assessment, i.e., to move toward the proposition for adaptation, swiftly by the implementation of these policies and plans.

For this, policies that go beyond mere goal setting are necessary. The iNDC should be linked to the Paris Agreement because, even if the concerns of the most vulnerable cities are addressed, there are other regions that lack safeguards within their powers of implementation.

Author Contributions: Conceptualization, P.H.C.T.; Data curation, D.A.G., K.L.d.S. and W.C.d.S.J.; Formal analysis, P.H.C.T.; Investigation, F.M.d.A.C., K.L.d.S. and K.C.; Methodology, D.A.G.; Supervision, P.H.C.T. and P.R.J.; Validation, K.C. and W.C.d.S.J.; Writing-original draft, P.H.C.T. and F.M.d.A.C.; Writing-review \& editing, P.H.C.T., F.M.d.A.C., K.L.d.S., K.C. and P.R.J. All authors have read and agreed to the published version of the manuscript. 
Funding: The São Paulo Research Foundation (FAPESP) funded this research, grant numbers 2015/03804-9, 2017/22067-0, 2019/11987-7, 2018/06685-9, and 2019/05644-0. This work was also carried out with the aid of a grant from the Inter-American Institute for Global Change Research (IAI): SGP-HW 056 (GovernAgua Project).

Institutional Review Board Statement: Not applicable.

Informed Consent Statement: Informed consent was obtained from all subjects involved in the study.

Data Availability Statement: Data available in a publicly accessible repository. The data presented in this study are openly available.

Acknowledgments: The authors would like to thank the reviewers for their suggestions, which helped improve this paper. The authors would like to thank Ana Lia Leonel (Figure 1), Igor Matheus Santa Chaves (Figure 2) and Rodolfo Baesso Moura (Figure 4).

Conflicts of Interest: The authors declare no conflict of interest.

\section{References}

1. Torres, P.H.C.; Cortes, P.L.; Jacobi, P.R. Governing complexity and environmental justice: Lessons from the water crisis in Metropolitan São Paulo (2013-2015). Desenvolvimento e Meio Ambiente (UFPR) 2020, 53, 61-77. [CrossRef]

2. Simões, E.; de Sousa Junior, W.C.; de Freitas, D.M.; Mills, M.; Iwama, A.; Gonçalves, I.; Olivato, D.; Fidelman, P.I.J. Barriers and opportunities for adapting to climate change on the North Coast of São Paulo, Brazil. Reg. Environ. Chang. 2017, 17, 1739-1750. [CrossRef]

3. Travassos, L.; Torres, P.H.C.; Giulio, G.D.; Jacobi, P.R.; de Freitas, E.D.; Siqueira, I.C.; Ambrizzi, T. Why do extreme events still kill in the São Paulo Macro Metropolis Region? Chronicle of a death foretold in the global south. Int. J. Urban Sustain. Dev. 2020, 1-16. [CrossRef]

4. Canil, K.; Lampis, A.; Santos, K.L. Vulnerabilidade e a construção social do risco: Uma contribuição para o planejamento na macrometrópole paulista. Cad. Metrop. 2020, 22, 397-416. [CrossRef]

5. Torres, P.H.C.; Ramos, R.F.; Pollachi, A. A macrometropolização em São Paulo: Reterritorialização, reescalonamento e a cidaderegião. Cad. Metrop. 2020, 22, 103-122. [CrossRef]

6. EMPLASA-Empresa Paulista de Planejamento Metropolitano. 2019. Available online: https://www.emplasa.sp.gov.br/RMSP (accessed on 14 November 2020).

7. Lencioni, S. Urbanização difusa e a constituição de megarregiões. O caso de São Paulo-Rio de Janeiro. Metropolis. Revista Eletrônica de Estudos Urbanos e Regionais 2015, 22, 6-15.

8. Torres, P.H.C.; Ramos, R.F.; Gonçalves, L.R. Conflitos Ambientais na Macrometrópole Paulista: Paranapiacaba e São Sebastião. Ambient. Soc. 2019, 22, e0101. [CrossRef]

9. Tavares, J. Formação da macrometrópole no Brazil: Construção teórica e conceitual de uma religião de planejamento. EURE 2018, 44, 115-134.

10. Pasternack, S.; Bogus, L.M. Macrometrópole paulista: Estrutura sócio-ocupacional e tipologia dos municípios—Mudanças na primeira década dos anos 2000. Revista Brazileira de Estudos Urbanos e Regionais 2019, 21. [CrossRef]

11. Travassos, L.; Zioni, S.M.; Torres, P.H.C.; de Souza Fernandes, B.; Araujo, G.M. Heterogeneity and spatial fragmentation in the São Paulo Macrometropolis: The production of borders and holes. Ambient. Soc. 2020, 23, e01801. [CrossRef]

12. Sovacool, B.K.; Brown, M.A. Scaling the policy response to climate change. Policy Soc. 2009, 27, 317-328. [CrossRef]

13. IPCC 2001. Climate Change 2001: Impacts, Adaptation, and Vulnerability, Contribution of Working Group II to the Third Assessment Report of the Intergovernmental Panel on Climate Change; Cambridge University Press: Cambridge, UK, 2001.

14. IPCC 2007. Climate Change 2007: Impacts, Adaptation and Vulnerability: Contribution of Working Group II to the Fourth Assessment Report of the Intergovernmental Panel; Cambridge University Press: Cambridge, UK, 2007.

15. IPCC 2012. Managing the Risks of Extreme Events and Disasters to Advance Climate Change Adaptation. A Special Report of Working Groups I and II of the Intergovernmental Panel on Climate Change; Field, C.B., Barros, V., Stocker, T.F., Qin, D., Dokken, D.J., Ebi, K.L., Mastrandrea, M.D., Mach, K.J., Plattner, G.-K., Allen, S.K., et al., Eds.; Cambridge University Press: Cambridge, UK, 2012.

16. IPCC 2014. Climate Change 2014: Impacts, Adaptation, and Vulnerability. Part B: Regional Aspects. Contribution of Working Group II to the Fifth Assessment Report of the Intergovernmental Panel on Climate Change; Barros, V.R., Field, C.B., Doken, D.J., Mastrandrea, M.D., Mach, K.J., Bilir, T.E., Chatterjee, M., Ebi, K.L., Estrada, Y.O., Genova, R.C., et al., Eds.; Cambridge University Press: New York, NY, USA, 2014.

17. Hagenlocher, M.; Meza, I.; Anderson, C.C.; Min, A.; Renaud, F.G.; Walz, Y.; Siebert, S.; Sebesvari, Z. Drought vulnerability and risk assessments: State of the art, persistent gaps, and research agenda. Environ. Res. Lett. 2019, 14, 083002. [CrossRef]

18. UN Framework Convention on Climate Change (UNFCCC). Paris Agreement, Decision 1/CP.21 (UNFCCC, 2015). 2015. Available online: https:/ / unfccc.int/resource/docs/2015/cop21/eng/10a01.pdf (accessed on 14 November 2020).

19. Bai, X.R.; Dawson, R.J.; Ürge-Vorsatz, D.; Delgado, G.C.; Barau, A.S.; Dhakal, S.; Dodman, D.; Leonardsen, L.; Masson-Delmotte, V.; Roberts, D.C.; et al. Six research priorities for cities and climate change. Nature 2018, 555, 23-25. [CrossRef] 
20. Di Giulio, G.M.; Torres, R.R.; Lapola, D.M.; Bedran-Martins, A.M.; da Penha Vasconcellos, M.; Braga, D.R.; Fuck, M.P.; Juk, Y.; Nogueira, V.; Penna, A.C.; et al. Bridging the gap between will and action on climate change adaptation in large cities in Brazil. Reg. Environ. Chang. 2019, 19, 2491-2502. [CrossRef]

21. Adger, W.N.; Brown, I.; Surminski, S. Advances in risk assessment for climate change adaptation policy. Phil. Trans. R. Soc. A 2018. [CrossRef]

22. Hoegh-Guldbert, O.; Jacob, D.; Taylor, M.; Guillen Bolaños, T.; Bindi, M.; Brown, S.; Camilloni, I.A.; Diedhiou, A.; Djalante, R.; Ebi, K.; et al. The human imperative of stabilizing global climate change at $1.5^{\circ} \mathrm{C}$. Science 2019, 365, eaaw6974. [CrossRef]

23. Davis, M.; Benzie, M.; Barrott, J. Transnational climate change impacts: An entry point to enhanced global cooperation on adaptation? SEI 2016, 2, 2-5.

24. Buchner, B.; Clark, A.; Falconer, A.; Macquarie, R.; Meattle, C.; Tolentino, R.; Wetherbee, C. Global Landscape of Climate Finance; CPI-Climate Policy Initiative: San Francisco, CA, USA, 2019.

25. Roelfsema, M.; van Soest, H.L.; Harmsen, M.; van Vuuren, D.P.; Bertram, C.; den Elzen, M.; Hohne, N.; Iacobuta, G.; Krey, V.; Kriegler, E.; et al. Taking stock of national climate policies to evaluate implementation of the Paris Agreement. Nat. Commun. 2020, 11, 2096. [CrossRef]

26. Angelo, C.; RittlI, C. Análise das Emissões Brazileiras de Gases de Efeito Estufa e Suas Implicações Para as Metas do Brazil; Observatiorio do Clima: Piracicaba, Brazil, 2019.

27. Hochstetler, K.; Viola, E. Brazil and the politics of climate change: Beyond the global commons. Environ. Politics 2012, $21,753-771$. [CrossRef]

28. Gurgel, A.C.; Paltsev, S.; Breviglieri, G.V. The impacts of the Brazilian NDC and their contribution to the Paris agreement on climate change. Environ. Dev. Econ. 2019, 24, 395-412. [CrossRef]

29. Brazil. Plano Nacional Sobre Mudança do Clima—PNMC, BRAZIL; Governo Federal, Comitê Interministerial Sobre Mudança do Clima: Brasília, Brazil, 2009. (In Portuguese)

30. UNFCCC. Federative Republic of Brazil Intended Nationally Determined Contribution Towards Achieving the Objective of the United Nations Framework Convention on Climate Change. 2016. Available online: https://www4.unfccc.int/sites/ndcstaging/ PublishedDocuments/Brazil\%20First/BRAZIL\%20iNDC\%20english\%20FINAL.pdf (accessed on 4 July 2020).

31. Brazil. Third National Communication of Brazil to the United Nations Framework Convention on Climate Change; Ministry of Science, Technology and Innovation: Brasília, Brazil, 2016; Volume 3.

32. Brazil. Plano Nacional de Adaptação à Mudança do Clima; Ministry of Environment: Brasília, Brazil, 2016.

33. Política Estadual de Mudanças Climáticas_PEMC; Governo do Estado de São Paulo: Sâo Paulo, Brazil, 2009.

34. Pelling, M.; Garschagen, M. Put equity first in climate adaptation. Nature 2019, 569, 327-329. [CrossRef] [PubMed]

35. UN Disaster Assessment and Coordination (UNDAC)—OCHA. Natural Disasters in Latin America and the Caribbean 2000-2019; OCHA: Panama, Panama, 2020.

36. Barbi, F. Mudanças Climáticas e Respostas Políticas Nas Cidades, 1st ed.; Editora da Unicamp: Campinas, Brazil, 2015 ; Volume 1, p. 246.

37. Empresa Paulista de Planejamento Metropolitano SA (Emplasa). Plano de Ação da Macrometrópole Paulista 2013-2040, 1st ed.; EMPLASA: São Paulo, Brazil, 2014.

38. Política Nacional de Proteção e Defesa Civil_PNPDEC. Brasília; 2012. Available online: http://www.planalto.gov.br/ccivil_03/_ Ato2011-2014/2012/Lei/L12608.htm (accessed on 28 June 2019).

39. Schlosberg, D. Climate Justice and Capabilities: A Framework for Adaptation Policy. Ethics Int. Aff. 2012, 26, 445-461. [CrossRef]

40. Schlosberg, D. Theorising environmental justice: The expanding sphere of a discourse. Environ. Politics 2013, 22, 37-55. [CrossRef]

41. Chou, S.C.; Lyra, A.; Mourão, C.; Dereczynski, C.; Pilotto, I.; Gomes, J.; Bustamante, J.; Tavares, P.; Silva, A.; Rodrigues, D.; et al. Assessment of Climate Change over South America under RCP 4.5 and 8.5 Downscaling Scenarios. Am. J. Clim. Chang. 2014, 3 , 512-527. [CrossRef]

42. Thomson, A.M.; Calvin, K.V.; Smith, S.J.; Kyle, G.P.; Volke, A.; Patel, P.; Delgado-Arias, S.; Bond-Lamberty, B.; Wise, M.A.; Clarke, L.E.; et al. RCP4.5: A pathway for stabilization of radiative forcing by 2100. Clim. Chang. 2011, 109, 77. [CrossRef]

43. Travassos, L.; Momm, S.; Torres, P. Notes on urbanization, Adaptation and Vulnerabilities in the SPMM. In Governance and Environmental Planning: Adaptation and Public Policy in the State Macro-Metropolis; Torres, P., Jacobi, P., Gonçalves, L., Barbi, F., Eds.; Letra Capital: Rio de Janeiro, Brazil, 2019; pp. 120-126.

44. Kowarick, L. A Espoliação Urbana; Paz e Terra: Rio de Janeiro, Brazil, 1993.

45. Maricato, E. Metrópole na Periferia do Capitalism; Hucitec: São Paulo, Brazil, 1996.

46. Villaça, F. Espaço Intra-Urbano no Brazil; Studio Nobel: São Paulo, Brazil, 1998.

47. Santos, M. A Urbanização Brazileira; EDUSP: São Paulo, Brazil, 2008.

48. SEADE (Fundação Sistema Estadual de Análise de Dados). 2020. Available online: www.seade.gov.br (accessed on 4 July 2020).

49. Ciccotti, L.; Rodrigues, A.C.; Boscov, M.E.G.; Gunther, W.M.R. Building indicators of community resilience to disasters in Brazil: A participatory approach. Ambient. Soc. 2020, 23, e01231. [CrossRef]

50. Canil, K.; Moura, R.B.; Sulaiman, S.N.; Torres, P.H.C.; Netto, A.L.A.; Jacobi, P.R. Vulnerabilidades, riscos e justiça ambiental em escala macro metropolitana. Mercator (UFC) 2021, 20, in press. 